JAROMÍR ŠIROKÝ, Ph.D. ${ }^{1}$

(Corresponding author)

E-mail: jaromir.siroky@upce.cz

PETR NACHTIGALL, Ph.D. ${ }^{1}$

E-mail: petr.nachtigall@upce.cz

JOZEF GAŠPARÍK, PhD. ${ }^{2}$

E-mail: jozef.gasparik@fpedas.uniza.sk

JIŘÍ ČÁP, Ph.D. ${ }^{3}$

E-mail: jiri.cap@oltisgroup.cz

${ }^{1}$ University of Pardubice

Faculty of Transport Engineering

Studentská 95, 53210 Pardubice, Czech Republic

${ }^{2}$ University of Žilina, Faculty of Operation

and Economics of Transport and Communications

Univerzitná 8215/1, 01026 Žilina, Slovakia

${ }^{3}$ OLTIS Group a.s.

Dr. Milady Horákové 1200/27a, 77900 Olomouc

Czech Republic
Transport Economics Original Scientific Paper Submitted: 12 Mar. 2020 Accepted: 25 Sep. 2020

\title{
CALCULATION MODEL OF RAILWAY CAPACITY PRICE IN THE CZECH REPUBLIC
}

\section{ABSTRACT}

This paper presents a pricing model of railway infrastructure capacity allocation functioning as a regulatory measure while fulfilling the regulatory requirements on railway infrastructure capacity allocation. The prices of railway infrastructure capacity allocation will be modelled with regard to all economically justifiable costs of railway infrastructure capacity allocation. The structure of model has been developed as a set of calculation sheets in Microsoft Excel. The recommended prices for railway capacity have been found by simulation of a set of variants and the recommendation is done for different operational conditions in an individual way. It analyses different products offered by the railway infrastructure capacity allocator both in the annual working timetable mode, and in the individual ad hoc mode. The aim of the proposed model is to motivate not only railway undertakings, but also the railway infrastructure capacity allocator to submit requests for railway infrastructure capacity in the annual working timetable mode rather than in the individual ad hoc mode. The total price is then verified to the cost of railway infrastructure capacity allocation. This process then ensures the regulation of the demand of railway undertakings on the given route and can influence the decision about the use of the product offered.

\section{KEYWORDS}

model; railway infrastructure; infrastructure access charges; charging system; railway capacity; timetable.

\section{INTRODUCTION}

The main railway transport regulation in the Czech Republic is the Act No. 367/2019 Coll., on Rail Systems, as amended. The Act contains provisions on railway infrastructure capacity allocation [1]. Gradually, the process of railway infrastructure capacity allocation was also influenced by the European legislation, namely by Directive 2012/34/ EU of the European Parliament and of the Council (after the Czech Republic joined the EU). Among other things, the Directive contains a provision governing the process of levying charges and railway infrastructure capacity allocation for allocators [2]. This made it possible for the railway infrastructure capacity allocators to start trading in available railway infrastructure capacity and ensure its potential optimal use. The Directive defines the minimum access package, i.e. a list of services to be provided by the railway infrastructure capacity allocators [3]. It specifies the scope of services related to access the infrastructure and service facilities, both in terms of basic and additional services.

The minimum access package according to Directive 2012/34/EU comprises the following [2]:

a) handling of requests for railway infrastructure capacity;

b) the right to utilise capacity which is granted; 
c) use of the railway infrastructure, including track points and junctions;

d) train control including signalling, regulation, dispatching and the communication and provision of information on train movement;

e) use of electrical supply equipment for traction current, where available;

f) all other information required to implement or operate the service for which capacity has been granted.

The minimum scope of the services offered is currently defined by the Decree No. 76/2017 Coll. In the Czech Republic, the assessing of railway infrastructure capacity and its allocation is defined by the Act No. 367/2019 coll., on Rail Systems, as amended, and the process of railway infrastructure capacity allocation is specified in the national and regional Rail Network Statement issued by the Railway Infrastructure Administration (RIA) for the given annual timetable [4]. The Act on Rail Systems defines the rights and obligations of the railway infrastructure capacity allocator (railway infrastructure manager - RIA) and of the individual railway undertakings (passenger and freight railway undertakings). Furthermore, the provisions of this Act stipulate that the process of railway infrastructure capacity allocation is based on the principle of non-discrimination, meaning that all railway undertakings can have access to railway infrastructure upon meeting the conditions required for operating the railway transport services. On state-owned national and regional rails, the railway infrastructure capacity allocator is the RIA [5]. On privately owned rails, the railway infrastructure capacity is allocated by an allocator appointed by the respective rail owner.

The focus of this research is on modelling to determine the price for capacity allocation by the creation of a timetable for railways in the Czech Republic. The aim is to find the optimal ratio between the offered routes on a regular schedule (individual products offered by the RIA) and train routes in the ad hoc mode. The evaluation criteria are the cost of rail capacity allocation and the cost of railway infrastructure allocation. Modelling the price for the allocation of rail capacity is an influence on the decisions of individual carriers to use the given products or to use train paths in the ad hoc mode. Within the EU, there is a regulation that requires the Railway Infrastructure Administration not to generate profit-making activities for the capacity allocation.
This is a very complex task for the Railway Infrastructure Administration, that has to set the price coefficients for the different types of requests to cover the costs associated with the capacity allocation within a period of 12 months, but at the same time not to make a profit. All these principles are analysed in the introduction part of the paper, including a search of available scientific papers on this topic. The novelty of the authors' approach is mainly that none of the available sources deals with this issue of modelling and does not address the possibility of modelling revenues from capacity allocation using mathematical apparatus.

\section{LITERATURE REVIEW}

According to the Rail Network Statement, the railway infrastructure capacity means the possibility to include train routes requested for specific rail sections for a specific time period [6]. It is expressed as the number of train routes which can be created in a specific time period given the existing technical, operational and personal capacities and maintaining the necessary transport quality.

According to internal regulations of the RIA, railway infrastructure capacity means the usable capacity of a rail allowing for the allocation of the required train routes on a specific rail section in a specific time period [7]

The allocation of railway infrastructure capacity means an action allowing for the use of such portion of total railway infrastructure capacity, which is necessary for the required train route. Until 2004, the railway infrastructure capacity had been allocated by the Office for Railways but since the annual timetable of 2005, the railway infrastructure capacity has been allocated independently by the allocator, i.e. by the RIA [8]. Levying charges for railway capacity allocation has developed in time as well. For setting the amount of charges for the railway infrastructure capacity allocation, the price of routeday and of the route used have been used since the beginning. Gradually, (since 2013), coefficients $\left(K_{1}, K_{2}\right.$, and $\left.K_{3}\right)$ have been added to the formula, reflecting the price per kilometre of the planned route, in addition to the price of route-day and of the route used. In the minimum access package, the total price is composed of the price of the railway infrastructure capacity allocation and the price for the use of the railway infrastructure through a train ride [9]. 
Determining traffic efficiency is tackled in [1012]. However, these only compare the railway line capacity indicators before and after the modernisation of the railway infrastructure. The actual process of traffic optimization on these lines is not described anywhere and the possibilities of train operation simulation are only described briefly [13]. It is only the demographic factors influencing the demand for public transport that are mostly taken into account [14].

The authors [15] deal with the capacity fees and connecting regional, national and local railways. For the purposes of that research, a model of the current and future situations was created. Based on the simulation model, several variants of operation of new passenger trains under new conditions were proposed and analysed. This study served as the basis for connecting national and regional railways in Croatia. The same was true for [16] that dealt with setting the railway infrastructure fees on regional railways.

The price of railway infrastructure capacity allocation is influenced by a number of factors. In addition to the processing complexity of a request, these include the length of the time interval between filing a request for the railway infrastructure capacity allocation and the requested date of railway use and whether the request is a request to be taken into account when creating the annual working timetable or an individual ad hoc request $[17,18]$. For setting the amount of charges for the railway infrastructure capacity allocation, the following Formula 1 was used:

$C_{I C A}=K_{1}+K_{2} \cdot D_{L}+K_{3} \cdot P_{D}$

where:

$C_{I C A}$ - price of railway infrastructure capacity allocation (EUR);

$K_{1} \quad$ - price of processing and determining the timetable and railway infrastructure capacity allocation (EUR);

$K_{2} \quad$ - price of train route creation [EUR per km];

$K_{3}$ - price of train route allocation per day [EUR per day];

$D_{L} \quad$ - route length [km];

$P_{D} \quad$ - number of route-days [day].

The price for the use of railway infrastructure is established based on the data on the length and parameters of the given rail, on the type of transport (passenger, freight) and on the parameters of the train including those that can have an impact on the basic, tender or increased prices [19]. The price for the use of railway infrastructure through a train ride includes the direct costs of ensuring the operability of the railway (maintenance and wear-and-tear repairs of the infrastructure due to the train ride) [20]. Furthermore, the price for the use of railway infrastructure through a passenger train ride includes the direct costs of maintenance and wear-and-tear repairs of access roads for passengers (not considered in calculating the price for the use of railway infrastructure through a passenger train are the costs of maintenance and repairs of fixed installations). [21]

The basic price for the use of railway infrastructure through a train ride is calculated according to Formula 2 using unit prices determined for passenger trains and freight trains [7]:

$C_{U R I}=C_{N T K}+C_{G T K}$

where:

$C_{U R I}$ - total basic price for the use of railway i nfrastructure through a train ride (EUR);

$C_{N T K}-$ price for the use of railway infrastructure through a train ride in the performance segment based on net train kilometres (EUR);

$C_{G T K}$ - the price for the use of railway infrastructure through a train ride in the performance segment based on gross train kilometres (EUR).

The requests for railway infrastructure capacity are processed electronically in IS KANGO (Complex application for on-line train diagram creation) or IS KADR (Railway capacity). Regular requests for railway infrastructure capacity to be taken into account when creating the annual working timetable and late requests for railway infrastructure capacity to be taken into account when creating the annual working timetable are processed in IS KANGO, whereas the individual ad hoc requests for railway infrastructure capacity are processed in IS KADR [22].

Different modes of railway infrastructure capacity allocation have been described in $[7,8]$. Detailed description is given on the basic classification of modes of railway infrastructure capacity allocation, including the mode of processing of annual timetable and its changes and the individual ad hoc mode. The authors not only describe the individual modes of railway infrastructure capacity allocation including their subgroups, but also the requirements on request target groups [23]. 
These are requests for railway infrastructure capacity to be taken into account when creating the annual timetable (products RJ - regular request for railway capacity allocation to be taken into account when creating the annual timetable, $\mathrm{PJ}$ - late request for railway capacity allocation to be taken into account when creating the annual timetable, and ZJ request for railway capacity allocation until the next change of the annual timetable) and ad hoc requests for railway infrastructure capacity (products N3 - ad hoc request for railway capacity allocation submitted three and more working days before the first requested date of train departure, P3 - ad hoc request for railway capacity allocation submitted later than three working days, TB - ad hoc request for railway capacity allocation for technical and safety tests, ZK - ad hoc request for railway capacity allocation for test rides of vehicles of unapproved type or rides at a speed exceeding the track speed, UI - ad hoc request for railway capacity allocation for RIA infrastructure maintenance, OM - ad hoc request for railway capacity allocation due to RIA infrastructure restrictions, and JD - ad hoc request for railway capacity allocation for other reasons attributable to the RIA) [8].

This segmentation has a significant impact on the modelling of price of railway infrastructure capacity allocation. For different products defined, the maximum railway infrastructure capacity values (i.e. route-days) are specified [24]. Furthermore, there is a basic formula for determining the price of railway infrastructure capacity allocation adapted and modified by the authors to be expressed as an inequation taking into account the maximum number of allocated route-days. This modification relied on the assumption that the products offered would be used optimally, allowing for maximum use of the products by the railway undertakings at a reasonable cost $[25,26]$.

Based on this modification, a break-even point was determined between different products for railway infrastructure capacity allocation in the annual timetable mode and in the ad hoc mode. The aim was to find a balance between the products offered, as far as the number of route-days are considered $[27,28]$.

Variant 0 was defined as the initial variant of the model, modelling the current situation and using the current way of railway infrastructure capacity allocation to determine the price of railway infrastructure capacity allocation for coefficients $K_{1}, K_{2}$ and $K_{3}$ for different products, with values applicable for 2019 [8].

The starting point for modelling the calculation formula is the determination of the following:

- Direct costs of railway infrastructure capacity allocation - the price of railway infrastructure capacity allocation depends on the system used for addressing the request and on the number of general routes requested. Taken into account in calculating the price of railway infrastructure capacity allocation are the operating costs of the RIA information systems and other professional activities necessary to include the general routes in the train timetable.

- Price of the railway infrastructure capacity allocation - the price of the railway infrastructure capacity allocation includes the payment for the process of railway infrastructure capacity allocation, payment for the creation of a train timetable (excluding the costs of printing and distributing the materials) allocated to the request of the applicant, and also the payment for the operational implementation of the train and the surcharge for short-term processing of the request.

\section{MODELLING OF RAILWAY INFRASTRUCTURE CAPACITY ALLOCATION}

The aim of modelling is to find the prices for the railway capacity. The simulation was based on a set of considered variants. The recommendation is done for different operational conditions in an individual way.

In [8], to model the price of the railway infrastructure capacity allocation, the authors presume that the revenue from the railway infrastructure capacity allocation must be higher or equal to the direct costs of allocation, i.e. that the costs of allocation must always be covered by the price of allocation.

The amounts of revenue are based on all the products offered (RJ, PJ, ZJ, N3, P3, TB, ZK, UI, $\mathrm{OM}$, and JD). The last three products (UI, OM, and JD) are negligible in relation to the total price of the railway infrastructure capacity allocation, and are not considered in further modulations of the calculation formula $[29,30]$.

Also taken into account is the processing of requests using the allocator's software tools IS KANGO and IS KADR. The IS KANGO tool is mainly used 
for processing requests for $\mathrm{RJ}, \mathrm{PJ}$, and $\mathrm{ZJ}$, while IS KADR is mainly used for processing requests for $\mathrm{N} 3$ and P3. In terms of complexity of processing, the ratio between $K_{1}$ value for requests processed in IS KANGO and requests processed in IS KADR was established as 0.06 .

As for $K_{1}$ for the individual products, the author established the following Formulas 3-7:

$$
\begin{aligned}
& K_{1 R J}=K_{1 R J} \\
& K_{1 P J}=K_{1 R J} \\
& K_{1 Z J}=K_{1 R J} \\
& K_{1 N 3}=0.06 \cdot K_{1 R J} \\
& K_{1 P 3}=K_{1 P 3}=0.06 \cdot K_{1 R J}
\end{aligned}
$$

The authors suggested coefficient $K_{2}$ by the following relations as $K_{2}$ reflects the construction complexity which remains constant with the changing price. The coefficient $K_{2}$ ratio for the individual products is again based on the current $K_{2}$ values and are as follows in Formulas 8-11:

$$
\begin{aligned}
& K_{2 R J}=K_{2 R J} \\
& K_{2 P J}=1.3 \cdot K_{2 R J} \\
& K_{2 Z J}=1.3 \cdot K_{2 R J} \\
& K_{2 P 3}=1.5 \cdot K_{2 N 3}
\end{aligned}
$$

The authors suggested coefficient $K_{3}$ by the following relations as $K_{3}$ reflects the scarcity of capacity which remains constant with the changing price. The coefficient $K_{3}$ ratio for the individual products is again based on the current $K_{3}$ values and are as follows in Formulas 12-15:

$$
\begin{aligned}
& K_{3 R J}=K_{3 R J} \\
& K_{3 P J}=1.3 \cdot K_{3 R J} \\
& K_{3 Z J}=1.3 \cdot K_{3 R J} \\
& K_{3 P 3}=1.5 \cdot K_{3 N 3}
\end{aligned}
$$

Coefficient $K_{1}$ is the price of administrative processing and assessing the processing complexity of a request for railway capacity allocation, and that is why always the same price applies to the annual timetable mode products which can be different in different calculation variants but always in the same way for all the annual timetable mode products
[31]. To all ad hoc products, the same coefficient $K_{1}$ price applies which is 0.06 times higher than the $K_{1}$ price for an annual timetable mode product. The authors maintained the current ratio between the annual timetable and ad hoc modes. Coefficient $K_{2}$ is the price per $\mathrm{km}$ of train route creation, and coefficient $K_{3}$ is the price per day of train route allocation. In all calculation variants, the authors proposed a non-zero price of coefficient $K_{2}$ per route kilometre for ad hoc products to take into account the route creation complexity. To motivate the railway undertakings and applicants to submit requests in the annual timetable mode, the coefficient $K_{1}$ price was reduced in all annual timetable mode products to EUR 56. A coefficient $K_{2}$ price of EUR 0.28 per km was established for RJ, with a coefficient $K_{3}$ price of EUR 0.36 per route-day being set for RJ as well.

A new limit number of route-days was calculated according to Formula 16 as a break-even point of price between products RJ and N3, and the number of route-days $P_{d j}$ was used as the unknown $x$. After substitution, the inequation is as follows:

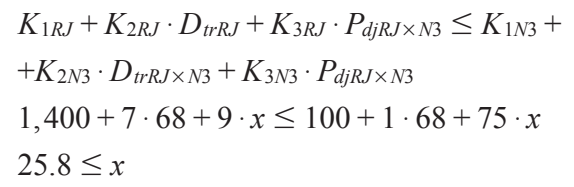

The limit value $x$ for the number of route-days for $\mathrm{RJ} \times \mathrm{N} 3$ was rounded to 26 .

The authors suggested the simplified expressions of coefficients $K_{1}, K_{2}$ and $K_{3}$ into equations and used the average number of kilometres $D_{t r}=68 \mathrm{~km}$ (average for the selected products RJ, PJ, ZJ, N3 and P3) and limit values for the number of route-days $P_{d j}=26$ days (break-even point of price between products RJ and N3). Total values were calculated using constants proposed earlier. After simplification, the inequation according to Formula 17 for the relation of $\mathrm{RJ}<\mathrm{N} 3$ for an average request is as follows:

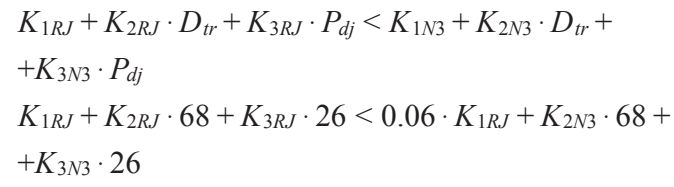

This condition stipulates that the price of a regular request for railway capacity allocation to be taken into account when creating the annual timetable for a limit number of route-days should be lower than the price of an ad hoc request for railway capacity allocation submitted three and more working days in advance for a limit number of route-days. 
After simplification, the inequation according to Formulas 18 and 19 for the relation of $\mathrm{RJ}<\mathrm{PJ} / \mathrm{ZJ}$ (the same form for both products) and for an average request for a limit number of route-days is as follows:

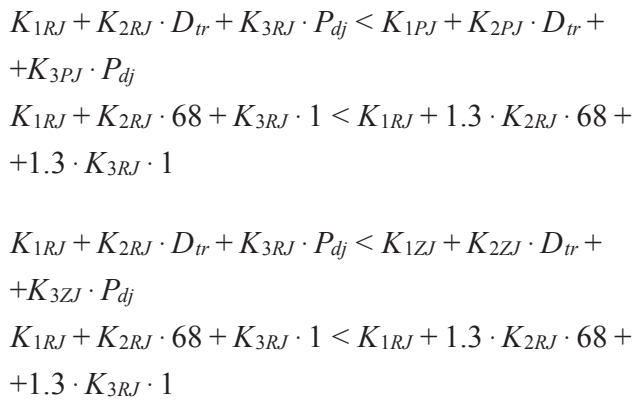

This condition stipulates that the price of a regular request for railway capacity allocation to be taken into account when creating the annual timetable for any number of route-days should be lower than the price of a late request and/or of a request until the next change of the annual timetable for any number of route-days. As the inequations have the same form for both products, they can only express one unknown.

After simplification, the inequation according to Formula 20 for the relation of $\mathrm{N} 3<\mathrm{P} 3$ for an average request for a limit number of route-days is as follows:

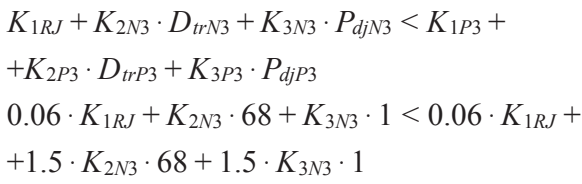

This condition stipulates that the price of an ad hoc request for railway capacity allocation submitted three and more working days in advance for any number of route-days should be lower than the price of an ad hoc request for railway capacity allocation submitted later than three working days in advance for this number of route-days.

These three inequations contain five unknowns. To express all the five unknowns, the author added another two complementary limiting conditions, increasing the number of inequations to five. After simplification, the inequation according to Formulas 21 and 22, which has the same form for both products, expressing the relation of $\mathrm{PJ} / \mathrm{ZJ}<\mathrm{N} 3$ and setting out the first complementary limiting condition is as follows:

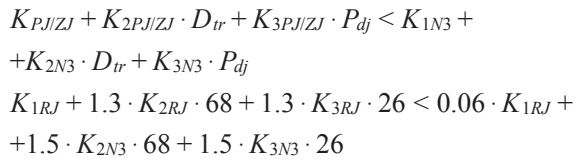

This first complementary limiting condition stipulates that the price of a late request for railway capacity allocation and/or of a request until the next change of the annual timetable for a limit number of route-days should be lower than the price of an ad hoc request for railway capacity allocation submitted three and more working days in advance for a limit number of route-days.

After simplification, the inequation according to Formula 23 setting out the second complementary limiting condition expressing the relation of $\left(P_{d j}-1\right)>\left(P_{d j}-1\right)_{3}$ is as follows:

$K_{1 R J}+K_{2 R J} \cdot D_{t r R J}+K_{3 R J} \cdot\left(P_{d j}-1\right)_{R J} R>K_{1 N 3}+$

$+K_{2 N 3} \cdot D_{t r N 3}+K_{3 N 3} \cdot\left(P_{d j}-1\right)_{N 3}$

$K_{1 R J}+K_{2 R J} \cdot 68+K_{3 R J} \cdot(26-1)_{R J}>0.06 \cdot K_{1 R J}+$

$+K_{2 N 3} \cdot 68+K_{3 N 3} \cdot(26-1)_{N 3}$

The second complementary limiting condition stipulates that the price of a request for railway capacity allocation to be taken into account when creating the annual timetable for a limit number of route-days minus one route-day should be higher than the price of an ad hoc request for railway capacity allocation submitted three and more working days in advance for a limit number of route-days minus one route-day.

After simplification, the inequation according to Formula 24 setting out another complementary limiting condition expressing the relation of $\left(P_{d j}-1\right)>\left(P_{d j}-1\right)_{3}$ s as follows:

$K_{1 P J}+K_{2 P J} \cdot D_{t r P J}+K_{3 P J} \cdot\left(P_{d j}-1\right)_{P J}>K_{1 N 3}+$

$+K_{2 N 3} \cdot D_{t r N 3}+K_{3 N 3} \cdot\left(P_{d j}-1\right)_{N 3}$

$K_{1 R J}+1.3 \cdot K_{2 R J} \cdot 68+1.3 \cdot K_{3 R J} \cdot(26-1)_{P J}>0.06 \cdot K_{1 R J}+$

$+K_{2 N 3} \cdot 68+K_{3 N 3} \cdot(26-1)_{N 3}$

The third complementary limiting condition stipulates that the price of a late request for railway capacity allocation to be taken into account when creating the annual timetable for a limit number of route-days minus one route-day should be higher than the price of an ad hoc request for railway capacity allocation submitted three and more working days in advance for a limit number of route-days minus one route-day.

After simplification, the inequation is as follows (25-31):

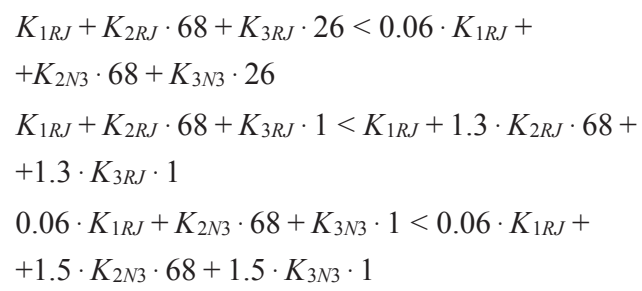


$K_{1 R J}+1.3 \cdot K_{2 R J} \cdot 68+1.3 \cdot K_{3 R J} \cdot 26<$

$<0.06 \cdot K_{1 R J}+K_{2 N 3} \cdot 68+K_{3 N 3} \cdot 26$

$K_{1 R J}+K_{2 R J} \cdot 68+K_{3 R J} \cdot(26-1)_{R J}>0.06 \cdot K_{1 R J}+$

$+K_{2 N 3} \cdot 68+K_{3 N 3} \cdot(26-1)_{N 3}$

$K_{1 R J}+1.3 \cdot K_{2 R J} \cdot 68+1.3 \cdot K_{3 R J} \cdot(26-1)_{P J}>$

$>0.06 \cdot K_{1 R J}+K_{2 N 3} \cdot 68+K_{3 N 3} \cdot(26-1)_{N 3}$

The authors [8] calculated Variant 0, laying down the coefficients using values applicable for annual timetable 2018/2019 (the total price of all products was EUR 4,385,292 and the costs of railway infrastructure allocation was EUR 4,271,200). For this variant, the value of $K_{2}$ for ad hoc products was 0 . The difference between revenue and costs was determined as EUR 114,092, which can be expressed as $2.67 \%$. To determine the revenue, limiting conditions were set for the individual products offered. These mainly include the number of limit kilometres for the individual products offered and the total number of requests for the railway infrastructure capacity for the given product.

The authors modelled six basic variants. In every variant, coefficients $K_{1}, K_{2}$ and $K_{3}$ were modified for different products offered to function as a regulatory measure, i.e. to ensure a balance between products offered to be taken into account when creating the annual working timetable and individual ad hoc products, and to comply with the applicable legislation.

For Variant 0.1 provided for the above, with the rate per $\mathrm{km}$ set at EUR 0.04 for $K_{2}$ in ad hoc products (with the other coefficient values left unchanged), the difference between revenue and costs of railway infrastructure allocation increased to EUR 514,804 (by $14.72 \%$ ) verified to the current situation (Variant 0 ). For Variant 0, the break-even point of price between the different products offered is shown in Figure 1 and Table 1.
Variant 1 - the authors created Variant 1 by substituting values into simplified inequations according to Formulas $25-31$ as a new calculation model reducing the coefficient $K_{1}$ price to EUR 56 per request in $\mathrm{RJ}, \mathrm{PJ}$ and $\mathrm{ZJ}$, and maintaining a constant of 0.06 in coefficient $K_{1}$ for N3 and P3 and a constant of 1.3 in coefficient $K_{2}$ and $K_{3}$ for PJ, ZJ, and a constant of 1.5 in coefficients $K_{2}$ and $K_{3}$ for P3, and introducing a coefficient $K_{2}$ price of EUR 0.04 per $\mathrm{km}$ for N3, P3, ZK and TB (ad hoc). The total revenue from the price of railway capacity allocation decreased to EUR 4,196,704, the revenue being by $1.74 \%$ lower than the costs of railway capacity allocation.

In Variant 1, the revenue from the price of railway capacity allocation decreased, but the total direct costs of railway capacity allocation remained higher than the revenue from the price of railway capacity allocation. By applying additional iterations and modelling, the authors came up with six calculation variants meeting the above-mentioned limiting conditions, achieving higher revenue from the price of railway capacity allocation through a moderate increase of the constants and the resulting coefficients $K_{1}, K_{2}$ and $K_{3}$.

Variant 2 - this variant involves increasing the coefficient $K_{3}$ price in PJ and ZJ to EUR 0.5 per route-day; the constants remained at $0.06 ; 1.3 ; 1.3$ and 1.5 , respectively. The total revenue from the price of railway capacity allocation increased to EUR 4,203,281, the revenue still being by $1.59 \%$ lower than the total direct costs of the railway capacity allocation.

Variant 3 - this variant involves increasing the constant value to 0.06 in coefficient $K_{1}$ for $\mathrm{N} 3$ and $\mathrm{P} 3$, increasing the constant value to $1.4 ; 1.4$, respectively, in coefficients $K_{2}$ and $K_{3}$ for PJ and $\mathrm{ZJ}$ and

Table 1 -Determining the price of railway infrastructure capacity allocation - Variant 0 (EUR)

\begin{tabular}{||c|c|c|c|c|c|c|c|c||}
\hline Product & $K_{1}$ & $\begin{array}{c}\text { Number of } \\
\text { data timetables }\end{array}$ & $K_{2}$ & $\begin{array}{c}\text { Total number } \\
\text { of kilometres }\end{array}$ & $K_{3}$ & $\begin{array}{c}\text { Number of } \\
\text { route-days }\end{array}$ & $\begin{array}{c}\text { Price of } \\
\text { product (EUR) }\end{array}$ & $\begin{array}{c}\varnothing \text { price per } \\
\text { request (EUR) }\end{array}$ \\
\hline \hline RJ & 68 & 13,686 & 0.32 & 731,593 & 0.4 & $2,899,051$ & $2,324,382$ & 169.83 \\
\hline PJ & 68 & 788 & 0.40 & 37,661 & 0.8 & 132,265 & 174,460 & 221.39 \\
\hline ZJ & 68 & 485 & 0.40 & 33,727 & 0.8 & 32,170 & 72,207 & 148.88 \\
\hline ZK & 38.4 & 285 & 0 & 11,492 & 2.8 & 367 & 11,972 & 42.01 \\
\hline TB & 19.2 & 196 & 0 & 9,742 & 2.8 & 196 & 4,312 & 22.00 \\
\hline N3 & 4 & 13,534 & 0 & $1,357,650$ & 2.8 & 26,400 & 128,056 & 9.46 \\
\hline P3 & 4 & 159,968 & 0 & $11,491,204$ & 6.4 & 160,943 & $1,669,907$ & 10.44 \\
\hline Total price (EUR) & & & & $4,385,296$ & 624.01 \\
\hline
\end{tabular}




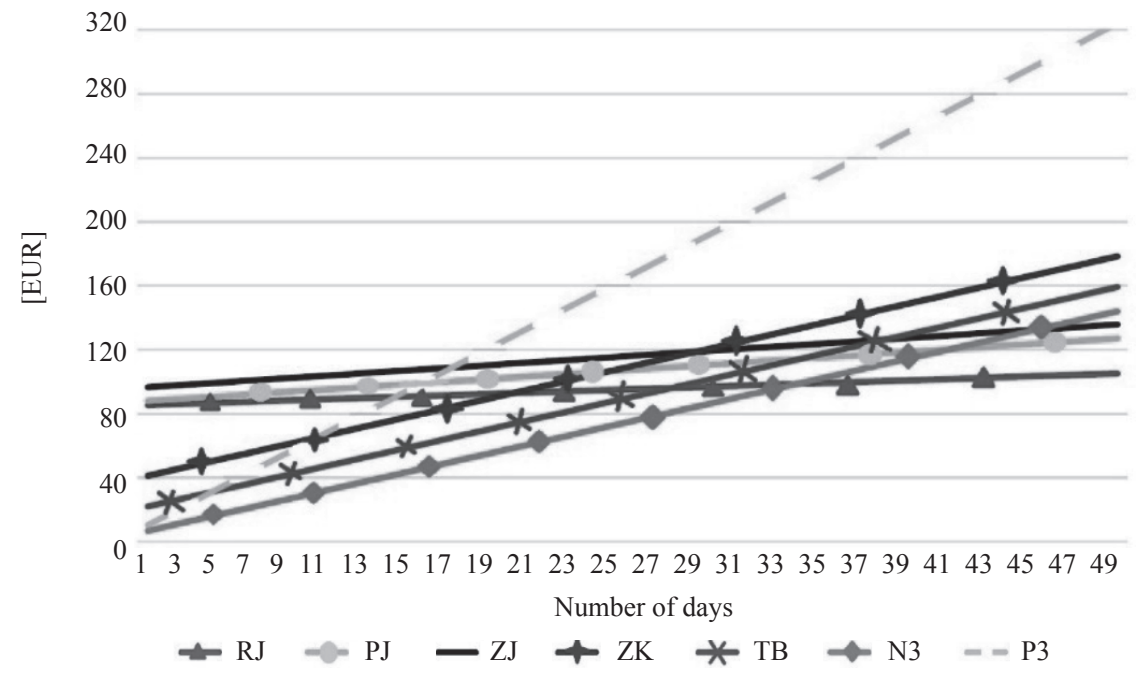

Figure 1 - Break-even point for different products offered-Variant 0

increasing the constant value to 1.6 in coefficient $K_{2}$ and $K_{3}$ for P3. This results in an increase in the coefficient $K_{2}$ price in PJ and ZJ to EUR 0.4 per km, and an increase in the coefficient $K_{3}$ price in PJ and ZJ to EUR 0.5 per route-day. In P3, the coefficient $K_{3}$ price increased to EUR 4.8 per route-day. The total revenue from the price of railway capacity allocation increased to EUR 4,273,889, being by $0.06 \%$ higher than the total direct costs of railway capacity allocation.

Another three calculation variants only resulted from changing the modelling in $\mathrm{ZK}$ and $\mathrm{TB}$, which are products for individual ad hoc requests for railway capacity allocation with higher demands on route creation and negotiation of technical procedures during the actual train ride. The change in these two products has no impact on the limiting condition inequations, the only changes involving the request price and the total revenue from the price of railway capacity allocation [32].

Variant 4 - in this variant, the coefficient $K_{2}$ price in $\mathrm{ZK}$ and TB was changed to EUR 0.1 per kilometre of route creation, with coefficients $K_{1}$ and $K_{3}$ left unchanged. The total revenue from the price of railway capacity allocation increased to EUR $4,275,588$, being by $0.10 \%$ higher than the total direct costs of railway capacity allocation.

Variant 5 - for modelling this variant, the coefficient $K_{1}$ price in ZK was increased to EUR 40 per request and the coefficient $K_{1}$ price in TB was increased to EUR 20 per request, and the coefficient $K_{2}$ price in ZK and TB remained at EUR 0.1 per $\mathrm{km}$ of route creation, with coefficient $K_{3}$ left unchanged. The total revenue from the price of railway capacity allocation increased to EUR $4,276,201$, being by $0.12 \%$ higher than the total direct costs of railway capacity allocation.

Variant $6-$ the coefficient $K_{1}$ price in ZK remained at EUR 40 per request and the coefficient $K_{1}$ price in TB remained at EUR 20 per request, and the coefficient $K_{2}$ price in ZK and TB was reduced to EUR 0.04 per $\mathrm{km}$ of route creation, with coefficient $K_{3}$ left unchanged. The total revenue from the price of railway capacity allocation increased to EUR 4,274,502, being by $0.08 \%$ higher than the total direct costs of railway capacity allocation.

\section{DISCUSSION}

The authors verified the individual calculation variants with the total direct costs of railway capacity allocation (see Table 2). The results of the individual calculation variants in Table 2 can be interpreted as follows:

Variant 0 - the current model for the calculation of the price of railway capacity allocation using coefficients $K_{1}, K_{2}$, and $K_{3}$. In 2019, the revenue from railway capacity allocation was $2.67 \%$ higher than the total direct costs of railway capacity allocation. Variant 0.1 - the current model introducing the coefficient $K_{2}$ price of EUR 0.04 per km of route creation in N3, P3, ZK and TB with coefficients $K_{1}$ and $K_{3}$ left unchanged. In 2019, the revenue from railway capacity allocation would have been $14.72 \%$ higher than the total direct costs of railway capacity allocation.

Variant 1 - a new model for the calculation of the price of railway capacity allocation reducing the coefficient $K_{1}$ price to EUR 56 per request in RJ, PJ 
Široký J, Nachtigall P, Gašparík J, Čáp J. Calculation Model of Railway Capacity Price in the Czech Republic

Table 2 - Comparison of revenue from railway capacity allocation with total direct costs of railway capacity allocation for the individual variants

\begin{tabular}{||c|c|c|c|c||}
\hline Variant & $\begin{array}{c}\text { Revenue from railway capacity } \\
\text { allocation (EUR) }\end{array}$ & & $\begin{array}{c}\text { Costs of railway capacity } \\
\text { allocation (EUR) }\end{array}$ & $\begin{array}{c}\text { Difference between revenue } \\
\text { and costs [\%] }\end{array}$ \\
\hline \hline Variant 0 & $4,385,292$ & $>$ & $4,271,200$ & 2.67 \\
\hline Variant 0.1 & $4,900,096$ & $>$ & $4,271,200$ & 14.72 \\
\hline Variant 1 & $4,196,704$ & $<$ & $4,271,200$ & -1.74 \\
\hline Variant 2 & $4,203,281$ & $<$ & $4,271,200$ & 0.06 \\
\hline Variant 3 & $4,273,889$ & $>$ & $4,271,200$ & 0.10 \\
\hline Variant 4 & $4,275,588$ & $>$ & $4,271,200$ & 0.12 \\
\hline Variant 5 & $4,276,201$ & $>$ & $4,271,200$ & 0.08 \\
\hline Variant 6 & $4,274,502$ & $>$ & $4,271,200$ & \\
\hline
\end{tabular}

Source: $[7,8,33]$

and $\mathrm{ZJ}$, and introducing a constant of 0.06 in coefficient $K_{1}$ for N3 and P3 and a constant of 1.3 in coefficient $K_{2}$ and $K_{3}$ for PJ, ZJ, and a constant of 1.5 in coefficients $K_{2}$ and $K_{3}$ for P3, and introducing the coefficient $K_{2}$ price of EUR 0.04 per km of route creation for N3, P3, ZK and TB (ad hoc). Using Variant 1 , the revenue from railway capacity allocation would have been $1.74 \%$ lower than the total direct costs of railway capacity allocation.

Variant 2 - the calculation reducing the coefficient $K_{1}$ price to EUR 56 per request in RJ, PJ and ZJ, and introducing a constant of 0.06 in coefficient $K_{1}$ for $\mathrm{N} 3$ and P3 and a constant of 1.3 in coefficient $K_{2}$ and $K_{3}$ for PJ, ZJ, and a constant of 1.5 in coefficients $K_{2}$ and $K_{3}$ for P3 and increasing the coefficient $K_{3}$ price in PJ and ZJ to EUR 0.5 per route-day. Using Variant 2 , the revenue from railway capacity allocation would have been $1.59 \%$ lower than the total direct costs of railway capacity allocation.

Variant 3 - the calculation reducing the coefficient $K_{1}$ price to EUR 56 per request in $\mathrm{RJ}, \mathrm{PJ}$ and ZJ, and introducing a constant of 0.06 in coefficient $K_{1}$ for $\mathrm{N} 3$ and $\mathrm{P} 3$ and increasing the constant value to 1.4 in coefficient $K_{2}$ and $K_{3}$ for PJ, ZJ, and increasing the constant value to 1.6 in coefficients $K_{2}$ and $K_{3}$ for P3. Using Variant 3, the revenue from railway capacity allocation would have been $0.06 \%$ higher than the total direct costs of railway capacity allocation.

Variant 4 - the calculation involving an increase in the coefficient $K_{2}$ price in ZK and TB to EUR 0.1 per $\mathrm{km}$ of route creation. Using Variant 4 , the revenue from railway capacity allocation would have been $0.10 \%$ higher than the total direct costs of railway capacity allocation.
Variant 5 - the calculation increasing the coefficient $K_{1}$ price in ZK to EUR 40 per request and coefficient $K_{1}$ price in TB to EUR 20 per request, and increasing the coefficient $K_{2}$ price in ZK and TB to EUR 0.1 per $\mathrm{km}$ of route creation. Using Variant 5, the revenue from the railway capacity allocation would have been $0.12 \%$ higher than the total direct costs of railway capacity allocation.

Variant 6 - the calculation increasing the coefficient $K_{1}$ price in ZK to EUR 40 per request and the coefficient $K_{1}$ price in TB to EUR 20 per request and reducing the coefficient $K_{2}$ price in $\mathrm{ZK}$ and TB to EUR 0.04 per $\mathrm{km}$ of route creation. Using Variant 6 , the revenue from the railway capacity allocation would have been $0.08 \%$ higher than the total direct costs of railway capacity allocation.

\section{PREDICTION FOR RAILWAY CAPACITY ALLOCATION IN 2020}

From internal resources of the RIA, the authors found out about the number of allocation requests by individual products in the annual timetables of 2018 and 2019 and the number of ad hoc allocation requests by individual products in 2018 and 2019 [8]. The data contain the number of allocated data timetables (number of routes), number of allocated route-days, total number of allocated kilometres, and the price of railway capacity allocation.

Using the percentage gains or losses in the reference years, the authors added data for 2020 as a prediction of the development of railway capacity allocation. The final prediction values for 2020 are shown in Table 3. 
Široký J, Nachtigall P, Gašparík J, Čáp J. Calculation Model of Railway Capacity Price in the Czech Republic

Table 3 - Prediction - allocated data timetables in 2020 - by products

\begin{tabular}{|c|c|c|c|c|c|c|c|}
\hline Product & $\begin{array}{l}\text { Number of } \\
\text { data } \\
\text { timetables }\end{array}$ & $\begin{array}{l}\text { Number of } \\
\text { route-days }\end{array}$ & $\begin{array}{l}\text { Total length } \\
{[\mathrm{km}]}\end{array}$ & $\begin{array}{l}\text { Total price } \\
\text { (EUR) }\end{array}$ & $\begin{array}{l}\varnothing \text { number of } \\
\text { route-days per } \\
\text { data timetable }\end{array}$ & $\begin{array}{c}\varnothing \text { length } \\
{[\mathrm{km} \text { per data }} \\
\text { timetable }]\end{array}$ & $\begin{array}{c}\varnothing \text { price [EUR } \\
\text { per data } \\
\text { timetable] }\end{array}$ \\
\hline RJ & 14,977 & $2,808,134$ & 847,778 & $2,401,643$ & 187.5 & 56.6 & 160.36 \\
\hline PJ & 1,548 & 192,213 & 56,553 & 276,415 & 124.1 & 36.5 & 178.56 \\
\hline ZJ & 518 & 23,823 & 27,535 & 63,467 & 46.0 & 53.1 & 122,52 \\
\hline N3 & 13,796 & 28,499 & $1,285,418$ & 134,871 & 2.1 & 93.2 & 9.78 \\
\hline P3 & 172,047 & 173,396 & $11,849,619$ & $1,797,924$ & 1.0 & 68.9 & 10.45 \\
\hline ZK & 449 & 744 & 15,974 & 19,219 & 1.7 & 35.6 & 42.80 \\
\hline TB & 328 & 328 & 12,731 & 7,223 & 1.0 & 38.8 & 22.02 \\
\hline UI & 73,297 & 72,989 & $1,807,459$ & 0 & 1.0 & 24.7 & 0 \\
\hline $\mathrm{OM}$ & 20,397 & 64,686 & $1,859,552$ & 0 & 3.2 & 91.2 & 0 \\
\hline JD & 1,417 & 2,5 & 68,796 & 0 & 1.8 & 48.6 & 0 \\
\hline Total & 298.774 & $3,367,312$ & $17,831,415$ & $4,700,762$ & 369.4 & 547.2 & 546.49 \\
\hline
\end{tabular}

Source: $[7,8,33]$

Table 4-Allocated data timetables: development in 2018, 2019 and prediction for 2020

\begin{tabular}{||c|c|c|c|c|c|c|c||}
\hline Product & $\begin{array}{c}\text { Number } \\
\text { of data } \\
\text { timetables }\end{array}$ & $\begin{array}{c}\text { Number of } \\
\text { route-days }\end{array}$ & $\begin{array}{c}\text { Total length } \\
{[\mathrm{km}]}\end{array}$ & $\begin{array}{c}\text { Total price } \\
\text { (EUR) }\end{array}$ & $\begin{array}{c}\varnothing \text { number of } \\
\text { route-days per } \\
\text { data timetable }\end{array}$ & $\begin{array}{c}\varnothing \text { length } \\
{[\mathrm{km} \text { per data }} \\
\text { timetable] }\end{array}$ & $\begin{array}{c}\varnothing \text { price } \\
\text { [EUR per data } \\
\text { timetable] }\end{array}$ \\
\hline \hline 2018 & 266,158 & $3,469,948$ & $16,325,204$ & $4,124,480$ & 13.0 & 61.3 & 15.49 \\
\hline 2019 & 281,569 & $3,404,399$ & $16,996,621$ & $4,385,292$ & 12.1 & 60.4 & 15.57 \\
\hline 2020 & 297,872 & $3,340,088$ & $17,695,651$ & $4,662,596$ & 11.2 & 59.4 & 15.65 \\
\hline
\end{tabular}

Comparing the total values of the allocated data timetables in 2018 and 2019 and based on the prediction for 2020, the authors want to point out the ever increasing number of allocated data timetables, increasing the length of allocated routes and the closely related increasing revenue from the price of railway capacity allocation [8]. The only decreasing value in Table 4 is the number of allocated route-days. This reflects the fact that the number of requests for railway capacity allocation for several route-days is decreasing, whereas the number of requests for railway capacity allocation for one route-day is increasing.

\section{CONCLUSION}

In the opening part of this paper, the authors defined the requirements on target groups of requests so that they can be attributed to individual products either in the mode of allocating railway capacity within the annual timetable, or in the ad hoc mode. This definition is vital for proper regulation of the demand of railway undertakings for individual products. The aim of the proposed model is for a part of the requests to move from the ad hoc mode to the annual timetable mode. For both modes to be based on the same conditions, the authors decided to introduce a non-zero price of coefficient $K_{2}$ per kilometre of route creation for ad hoc products in all calculation variants. This leads to an increase in the request price in the ad hoc mode. To motivate the railway undertakings and applicants to submit the requests in the annual timetable mode, the coefficient $K_{1}$ price was reduced in all annual timetable mode products to EUR 56. Table 2 shows the comparison of the different calculation variants. Only two variants, namely Variant 1 and Variant 2, meet the limiting conditions, mainly the condition stipulating that the total revenue from the price of railway capacity allocation should not exceed the total direct costs of railway capacity allocation. More advantageous is Variant 2, as the difference between revenue and costs is lower. However, the authors favour Variant 3 as it is closest to the quantified total direct costs of railway capacity allocation. 
Even though the revenue from the price of railway capacity allocation exceeds the costs by $0.06 \%$, not meeting the condition that revenue should not exceed direct costs, this variant provides the greatest balance between revenue and direct costs. From internal data for 2018 and 2019 provided by the RIA, the authors calculated year-on-year gains and losses of the individual products and based on these values, they tried to predict the development of railway capacity allocation in 2020 .

The authors came up with a mathematical pricing model of railway capacity allocation. This model can be modified according to the required outputs. The different calculation variants will vary based on the parameters entered. It will be only up to the RIA as the railway capacity allocator to decide whether to use Variant 2, or Variant 3 recommended by the authors or any other calculation variant as the future pricing model for railway capacity allocation. All the proposed calculation variants include the coefficient $K_{2}$ price per kilometre of route creation in ad hoc products. A great limitation in creating this model was the regulatory requirement that the revenue from the railway capacity allocation cannot exceed the total direct costs of railway capacity allocation. From the point of view of applying the results in practice, it is necessary to preserve the principles of liberalization and non-discrimination.

\section{ACKNOWLEDGEMENTS}

The work was supported from ERDF/ESF "Project PosiTrans - University of Pardubice cooperation and application sphere in application oriented research of localization, detection and simulation systems for transport processes" (No. CZ.02.1.01/0. 0/0.0/17_049/0008394).

JAROMÍR ŠIROKÝ, doc. Ing. Ph.D. ${ }^{1}$

E-mail: jaromir.siroky@upce.cz

PETR NACHTIGALL, Ing. Ph.D. ${ }^{1}$

E-mail: petr.nachtigall@upce.cz

JOZEF GAŠPARÍK, prof. Ing. PhD. ${ }^{2}$

E-mail: jozef.gasparik@fpedas.uniza.sk

JIŘí ČÁP, Ph.D. ${ }^{3}$

E-mail: jiri.cap@oltisgroup.cz

${ }^{1}$ Univerzita Pardubice

Dopravní fakulta Jana Pernera

Studentská 95, 53210 Pardubice, Česká republika

2 Žilinská univerzita v Žiline, Fakulta prevádzky

a ekonomiky dopravy a spojovs

Univerzitná 8215/1, 01026 Žilina, Slovensko

3 OLTIS Group a.s.

Dr. Milady Horákové 1200/27a, 77900 Olomouc

Česká republika

\section{MODEL PRO STANOVENÍ CENY ZA Pर̌IDĚLENÍ KAPACITY DRÁHY}

$V$ př́spěvku je prezentován model pro stanovení ceny za přidělení kapacity dráhy, který plní funkci regulačního opatření a zároveň splni legislativní požadavky na pridělování kapacity dráhy. Za pomoci programu MS Excel jsou namodelovány sazby ceny za kapacitu dráhy tak, aby byly zohledněny všechny ekonomicky oprávněné náklady na pridělováni kapacity dráhy a zároveň bylo dosaženo takové ceny za pridělování kapacity dráhy, která by dopravce motivovala $k$ optimálnímu objednávání jednotlivých produktů. Jsou zde analyzovány jednotlivé nabizené produkty, které jsou přidělcem kapacity dráhy nabizeny a to jak v režimu plánovaného ročního jízdního řádu, tak v režimu individuálního ad hoc. Využití jednotlivých produktů v rámci žádosti o přiděleni kapacity dráhy jsou ovlivněny r̆adou faktori̊ jak ze strany př́dělce kapacity dráhy, tak i ze strany dopravcü. Cílem navrhovaného modelu je motivovat nejen dopravce, ale $i$ prídělce kapacity dráhy o prechod v podávání žádostí o přidělení kapacity dráhy z režimu individuálního ad hoc do režimu ročního harmonogramu. Jde o nastavení parametrů jednotlivých nabizených produktů prídělce, kterým je ovlivněna celková cena za přidélení kapacity v jednotlivých režimech. Ta je pak porovnávaná s nákladovou stránkou procesu přidélováni kapacity dráhy. Tento proces pak slouži k zajištění regulace poptávky železničních dopravců na dané dráze a může vést $k$ ovlivnění rozhodnutí o využití nabizeného produktu.

\section{KLÍČOVÁ SLOVA}

model; železniční infrastruktura; kapacita železnice; poplatky za př́stup $k$ infrastruktuře; manažer infrastruktury; jizdní řád.

\section{REFERENCES}

[1] Act No. 367/2019, Czech Republic, from 15 January 2020, about Rail Systems, actual version 2020. Available from: https:/www.zakonyprolidi.cz/cs/2019-367

[2] Derective 2012/34/EU of the European Parliament and of the council of 21 November 2012, establishing a single European railway area. Available from: https:// eur-lex.europa.eu/legal-content/CS/TXT/?uri=CELEX\%3A32012L0034

[3] RNE. RailNetEurope 2018. Available from: http://www. rne.eu/members_ns

[4] Sramek P, Siroky J, Hlavsova P. Capacity range-definition and calculation. MATEC Web of Conferences. 2018;235: 00017. DOI: $10.1051 /$ matecconf $/ 201823500017$

[5] Railway Infrastructure manager (SŽDC), Network Statement 2018. Available from: https://www.szdc.cz/dopravci/prohlaseni-o-draze/prohlaseni-o-draze-2018.pdf

[6] Gasparik J, Siroky J, Peceny L, Halas M. Methodology for assessing the quality of rail connections on the network. Communications: Scientific Letters of the University of Zilina. 2014;2: 25-30. 
[7] Siroky J. Price for the Allocation of Railway Infrastructure Capacity as a Tool for the Improvement of Train Transport Planning. MATEC Web of Conferences. Vol. 134: $18^{\text {th }}$ International Scientific Conference - LOGI. Les Ulis: EDP Sciences; 2017. p. 1-7.

[8] Siroky J, Salakova H. Analysis of the system of pricing of railway capacity allocation in the Czech Republic. MATEC Web of Conferences. 2018;235: 1-12.

[9] Purwanto AJ, Heyndrick Kiel J, Betancor O, Socorro M, Hernandez A, Eudenio-Martin JL, Pawlowska B, Borkowski P, Fiedler R. Impact of transport infrastructure on international competitiveness of Europe. Transportation Research Procedia. 2017;25: 2877-2888.

[10] Fraszczyk A, Marinov M. Sustainable Rail Transport: Proceedings of RailNewcastle. Springer; 2018. p. 307.

[11] Dolinayova A, Cerna L. Passenger and freight transport performances in the regional railway line and their impact to the state budget requirements - Case study in Slovakia. Proceedings of the $23^{\text {rd }}$ international scientific conference Transport Means; 2019. p. 148-152.

[12] Lalinska J, Camaj J, Mašek J, Nedeliaková E. Possibilities and solutions of compensation for delay of passenger trains and their economic impacts. Proceedings of the $19^{\text {th }}$ international scientific conference on Transport Means; 2015. p. 183-186.

[13] Ljubaj I, Mikulčić M, Mlinarić TJ. Possibility of Increasing the Railway Capacity of the R106 Regional Line by Using a Simulation Tool. Transportation Research Procedia. 2020;44: 137-144.

[14] Sipus D, Abramovic B. The possibility of using public transport in rural area. Procedia Engineering. 2017;192: 788-793.

[15] Mikulčić M, Petrović M, Ljubaj I. Analysing the Railway Passenger Train Operation Using a Simulation Model. Proceedings of the international conference Horizons of Railway Transport, Strecno, Slovakia; 2017. p. 122-128.

[16] Abramović B, Pagasić Skrinjar J, Sipus D. Analysis of railway infrastructure charges fees on the local passenger lines in Croatia. Proceedings of the Third International Conference on the Traffic and Transport Engineering (ICTTE); 2016. p. 918-923.

[17] International Union of Railways. UIC CODE 406 $2^{\text {nd }}$ edition; 2013. Available from: https://tamannaei. iut.ac.ir/sites/tamannaei.iut.ac.ir/files//files_course/ uic406_2013.pdf

[18] Dolinayova A, Loch M, Camaj J. Liberalization of the railway freight market in the context of a sustainable transport system. Transp. Res. Procedia. 2016;14: 916925.

[19] Stoilova SD. An Integrated Approach for Selection of Intercity Transport Schemes on Railway Networks. Promet - Traffic\&Transportation. 2018;30(4): 367-377. Available from: https://traffic.fpz.hr/index.php/PROMTT/article/view/2673

[20] Abramovic B, Sipus D. A Case Study of the Railway
Engineering Programme; Sustainable Rail Transport. Berlin/Heidelberg, Germany: Springer; 2019. p. 101-109.

[21] Siroky J, Cempirek V, Gasparik J. Transport Technology and Control. Brno: Tribun EU; 2014. p. 238.

[22] Mankowski C, Weiland D, Abramović B. Impact of Railway Investment on Regional Development - Case Study of Pomeranian Metropolitan Railway. Promet Traffic\&Transportation. 2019;31(6): 669-7. Available from: https://traffic.fpz.hr/index.php/PROMTT/article/ view/3231

[23] Valdivia LJ, Solas G, Añorga J, Arrizabalaga S, Adin I, Mendizabal J. ETCS On-board Unit Safety Testing: Saboteurs, Testing Strategy and Results. Promet - Traffic\&Transportation. 2017;29(2): 213-222. Available from: https://traffic.fpz.hr/index.php/PROMTT/article/ view/2171

[24] Gattuso D, Restuccia A. A tool for railway transport cost evaluation. Procedia - Social and Behavioral Sciences. 2014;111: 549-558.

[25] Poliakova B, Kubasakova I, Kubanova J. Closed System Simulation in the Road Freight Transport. $19^{\text {th }}$ International Scientific Conference on Transport Means 2015, Kaunas, Lithuania. 2015. p. 199-202.

[26] Dewild T, Sels P, Cattrysse D, Vansteenwegen P. Robust railway station planning: An interaction between routing, timetabling and platforming. Journal of Rail Transport Planning and Management. 2013;3(3): 68-77.

[27] Hamacher HW, Liebers A, Schobel A, Wagner D, Wagner F. Locating new stops in a railway network. Electronic Notes in Theoretical Computer Science. 2001;50(1): 13-23.

[28] Armstrong A, Meissner J. Railway Revenue Management: Overview and Models. Lancaster, UK: Lancaster University Management School; 2010. p. 1-24.

[29] Yuan T, Simin H, Jikun L. Application of revenue management in European and American railways. China Railw. 2008;6: 63-66.

[30] Bazant M, Bulicek J, Kryze P, Vesely P. Calculation of the capacity of switch area within railway stations with use of simulation methods. $29^{\text {th }}$ European Modeling and Simulation Symposium, EMSS. Rende: CAL-TEK SRL; 2017. p. 316-322.

[31] Abramović B. Passenger's satisfaction on long distance terminals: Case study city of Zagreb. Periodica Polytechnica Transportation Engineering. 2017;45(1): 42-47.

[32] Chovancová M, Stopka O, Klapita V. Modeling the distribution network applying the principles of linear programming. Proceedings of the $21^{\text {th }}$ international $\mathrm{sci}$ entific conference on Transport Means. Juodkrante, Lithuania: Kaunas University of Technology; 2017. p. 73-77.

[33] Bougna E, Crozet Y. Towards a liberalized rail transport: Analyzing and modelling the impact of competition on productive efficiency. Res. Transp. Econ. 2016;59: 358-367. 